\title{
Moral Choice of a Man of Modernity in the Context of the Genealogical Method of F. Nietzsche
}

\author{
Alexandra Kosorukova \\ Department of Ethics \\ Faculty of Humanities and Social Sciences \\ Peoples' Friendship University of Russia \\ Miklukho-Maklaya str., 10/2, Moscow, Russia 117198 \\ E-mail: a.kosorukova@yandex.ru
}

\begin{abstract}
The article concerns the influence of Nietzsche's ethics in the context of the understanding of moral choice in non-classical rationality. It is asserted that the method of genealogy in ethics leads to understanding of the idea of nonmoral roots of moral choice. This view reveals parallels in understanding of moral choice and in the features of nonclassical thinking about a man, a man of modernity.
\end{abstract}

Keywords-moral choice; ethics; Nietzsche's genealogical method; ressentiment; post-classical philosophy

\section{INTRODUCTION}

Nietzsche is considered to be the thinker, that sets, along with S. Kierkegaard, K. Marx and S. Freud, the turn to modern philosophy [1], which largely determines specificity of modernity as post-classical thinking. The philosophy of Friedrich Nietzsche is an example of criticism of the classical idealism and the Enlightenment project, which gives perspective of the man, his will and morals that are still relevant and require new interpretations.

As noted by Martin Heidegger, Nietzsche embodying their task of modern criticism of metaphysics itself remains at its base [2] (creating new metaphysical constructs). Also J. Habermas in his criticism of the paradigm of education, said that the criticism of modernism, Nietzsche falls into performative contradiction, criticizing modern, while remaining committed to the concepts and ideas of modernity [3]. In this sense, the figure of Nietzsche in the context of the consideration of classical and post-classical rationality specifies additional questions about the attribution of modernity to postclassic and criticism in the modern classics and reason the modern. Of particular interest is the question of ethical perspective criticism classics and modern project, which affects the attitude to the concept of morality and moral in their classical and non-classical formulations. Consider the example of Nietzsche's philosophy is the problem of moral choice, as it appears in the context of the critique of morality in post-Enlightenment project of Nietzsche.

The moral choice of the person is the concept that, in many respects, poses morality as a phenomenon of individual personal consciousness. Moral choice belongs to the individual as the substance of ethical qualities, the subject of ethical assessments, and the one who carries out these assessments: it is the moral choice actualizes the question of the moral law and the categories of morality, by which he deals with people for the ethical quality and evaluation. The moral choice of the person as a concept of ethics defines its subject as perhaps no other moral category, because it is an ethical choice that focuses in the essential features of moral consciousness as intention and selfregulation (Aristotle), the autonomy of the practical reason (Kant), the issue of criteria for good, responsibility issues, etc.

The article is devoted to understanding of moral choice in non-classical rationality that is accepted through the Nietzsche's genealogical method. The choice of the focusing on this very ground of non-classical thinking is caused by the idea that it can be useful for the theory of morality to guide the lines of understanding of the moral choice in the context of the non-classical method.

\section{Genealogical Method of F. NiETZSCHE AND THE IDEA OF RESSENTIMENT}

The concept of moral choice is determined by those contexts, which are defined in the context of other ethical and philosophical doctrine. In post-Enlightenment philosophy a critique of morality examines its historical roots and raises the question about the relativity of moral choice, or lack of reason to talk about individual moral choices among a number of diverse pragmatic choices. When Nietzsche says that man is only more declined to his abyss when he was warned against it, or Kierkegaard argues that the religious stage is overcoming ethical, we are dealing with a new way of talking about values of human life.

Genealogical method of Nietzsche, as one of the most important discoveries in ethics, sets the basis for the question about how moral choice occurs and what are the possible distortion of morality in moral choice. Genealogy as the origins of moral concepts is opposed on the one hand to the transcendentalism of the Enlightenment project (the proposal of perfection of reason and belief in the possibility of logical unity), and on the other hand, popular in the 19th century 
historicism (postulating an internal logic and isomorphism between the past and the present, admiration of the past) [4].

Genealogical method pays attention to the uncertainties in the justification of the idealistic notions of good. Wondering about the roots of the word usage, Nietzsche raises the notion of good to the concept of noble, noble pedigree in their contrast to low, vulgar, plebeian (that is conceived as evil). Moral choice in this case - the question of choosing good and rejecting evil - is completely defined by the named definition of good and evil.

However, and this is the criticism of historicism, morality in the modern sense generated by the overturn of the original meaning of good and evil, and hence the distortion of the essence of moral choice. The morality of modern European humanity derives from the slave revolt in morality, accomplished in historical Christianity with the principle of ressentiment, or the revenge of the weak. Moral choice becomes the choice of the weak and insignificant (even Nothing in the case of ascetic ideals), as the moral values postulated on the basis of feelings of hostility to the strong and frightening great. The point of return to the knightlyaristocratic morality expressed by the following ideals: "...grant me just one glimpse of something perfect, completely finished, happy, powerful, triumphant, that still leaves something to fear! A glimpse of a man who justifies man himself, a stroke of luck, an instance of a man who makes up for and redeems man, and enables us to retain our faith in mankind!" [5. P. 25].

One of the fundamental implications for theories of morality from the genealogical method is the idea of causation of moral by immoral motives. This idea is concretized in the "Genealogy of morality" in reasoning about the concept of guilt and conscience ("conscience"), asceticism (such as the ascetic priest) [6. P. 1311].

\section{RESSENTIMENT AND THE CRITICS OF THE CLASSICAL AND MODERN RATIONALITY}

The idea of causation of moral choice by immoral motives plays an ambivalent role in the thought of Nietzsche. On the one hand, this idea is a criticism of the alienated existence of the moral consciousness, which par excellence, for Nietzsche, is built on immoral requirements (on the slave revolt in morality). On the other hand, it raises the question of the moral status of consciousness (and of moral choice) as fundamentally alienated consciousness. Due to this approach, morality is based on the will to power of goal setting (the morality of the Superman). The first unworthy consequence for morality is the immoral force of such a base (Nietzsche said that Christianity destroys himself, referring to the principle of veracity). The second is that the morality of the Superman is based on the will to power as principle, which also is perceived to be a classical (Aristotelian and Kantian) principle, where goodness is an end in itself (an Autonomous sense of morality).

Perhaps it is the understanding of Nietzsche through the criticism of classical and modern moral theory that helps us to understand the will to power as the basis of morality in a sense of autonomous ethics. Bringing down morality from the world of transcendental ideas is caused by criticism not only of immorality of motives of alienated morality, but also by a call to unite abstract-universal character of morality with a particular personal motive. Criticism of the alienation of abstract morality, paradoxically, aims at clarifying the meaning of its intrinsic value, and not formal one but appealing to the personal choice.

In the ethics of Nietzsche, we see the following characteristics of non-classical rationality, as they were defined by M. Mamardashvili: 1) "opacity" of the Subject (agent) for logical understanding, 2) the influence of the Subject on the process of observation, 3) definition of the Subject and its properties by activities [7]. These signs are directly connected with ethical-psychological discoveries of Nietzsche, which is largely responsible for the historical turn of thinking to these new properties (non-classical thinking).

- The opacity of the Subject of moral choice (the subject, justifying the act) is expressed in the idea of the irreducibility of values to the external reactions (that can lead to the idea of non-ressentimental value posing).

- The influence of the subject on the process of moral choice means not only the influence on the choice of means, but on the connection of value posing with the will to power - which cannot be ignored, otherwise we come to nihilistic line of positing values (the object of Nietzsche's critics).

- The definition of the subject by his activities, his life circumstances, his desire to the most powerful life is the idea that, by Nietzsche, cannot be dismissed from the thoughts without the harmful effects to the will.

Moreover, the will to power as will to life and assert themselves every time, according to Nietzsche, provides a reassessment of values, but not in the sense of response to what is denied, but in the sense of production values in the way of growth and self-exaltation of both the cultiveted and further cultivating life.

The crucial post-classical implementations of Nietzsche's genealogical method can be found in Nietzsche's reception of Deleuze and Derrida. The influential post-classical thinker Gilles Deleuze focuses on Nietzsche's idea that "the critique of reason is not a method, but is achieved by "culture" in the Nietzschean sense: training, discipline, inventiveness, and a certain cruelty" [8] (see Deleuze [9]). Cruelty in this context could be perceived as a way of dealing with self-assertion that includes necessarily recapturing the field of non-logical and extra-logical. In this sense, Derrida's antilogocentrism insists that "reading, and therefore writing, the text was for Nietzsche 'originary' operations," [10. P. 19], and this puts him at the closure of metaphysics (not the end), a closure that liberates writing from the traditional logos, which takes writing to be a sign (a visible mark) for another sign (speech), whose "signified" is a fully present meaning" [8].

The both examples give the wide perspective of what is called genealogical method. This perception of the method 
can be exaggerated over the issue if the moral choice, though the theme of moral choice is found in Nietzsche rarely, if talking about the literal term "moral choice".

\section{REJECTON OF RESSENTIMENT AS A FORM OF OVERCOMING NIHILISM OF THE CLASSICAL AND MODERN MORALITY}

We see the term "moral choice", this symbol of choice between good and evil, through such concepts as "the postulation of values," "the assertion of the will to power." The question of why this is so, can help to reveal the attitude of Nietzsche's morality in its classical forms and formulations.

"There are the terrible ones who carry about in themselves the beast of prey, and no choice except lusts of self-laceration. And even their lusts are self-laceration"[11] says one of the aphorisms of Zarathustra. One of the few references on the problem of selection points to a crucial dead-end choice of those who preach the abhorrence of life (Chapter "Of Preachers of death"). Another important fragment on the issue of choice, more in connection with it: "It is the truth, however, that the good MUST be Pharisees-they have no choice! The good MUST crucify him who deviseth his own virtue! That IS the truth!..The CREATOR, hate they most, him who breaketh the tables and old values, the breaker,--him they call the law-breaker. For the good-they CANNOT create..."[12].

Both fragments cannot be adequately understood without Nietzsche's theory of ressentiment. Interpretation of the certain kind of people who hate the destructive because they don't see it as a creative moment gives an example of psychological analysis of the phenomenon of ressentiment. "Good" in Nietzsche's understanding are often criticized because of the fact that they can destroy the true Creator (including perhaps themselves). Resentment as a feeling of weakness or inferiority in some way, generating offense as a way to the only available response (and perhaps in principle the only possible response; Nietzsche emphasizes that resentment is the principle of response to external stimulus, and not by the positing of values in one's own personal willing) is the feeling that describes one of the alternatives of moral choice. that should be avoided.

Then, the rationality of choice is caused by determination of reasonable and conscious motive of direct goal setting, excluding any double bottom, the meanings of "response to external stimulus", which deny the creativity will. That is, the rationality of the choice itself is opposite to ressentment as a principle. The paradox of ressentiment, in which one falls, hating the resentment (blaming somebody in ressentiment is resentment itself) is removed by an important structural moment that such a comparison oneself with resentment should be carried out only in respect of this very oneself. Let's call this feature of goal setting in moral choice (excluding ressentiment in himself) reflexive struggle with resentment. So, it is reflexive struggle with resentment that is the basis of moral choice, which is responsible for rational selection criteria. It finds its expression in the criteria of increasing the will to power as the criterion of the act (as we understand morality as morality is not a herd, a morality of the Superman) [13. P. 52]. Although the Superman is rarely mentioned in the context of genealogical method (he is only mentioned once in the Genealogy [14. P. 282]), Nietzsche definitely points at a man of the future - "post-modern" man: "this Antichrist and anti-nihilist, this conqueror of God and nothingness - he must come one day" [15. III, 24].

So, the question why the term "moral choice" as the theme of choice between good and evil, almost is not found in Nietzsche, we saw the following response: Nietzsche postulates a departure from the classic binary oppositions, of thinking about the extremes, including morality (vice-virtue, two extreme opposites of the metaphysical concepts of Good and Evil). The perception of Nietzsche through criticism of classical language in moral theory helps to understand the meaning of the will to power as the basis of morality in a sense of autonomous ethics and its applied aspects.

\section{CONCLUSION}

Concluding the conversation about the moral choice, it is to be summarized, that Nietzsche in the development of the idea of human choice between good and evil, between the decent and indecent, important and insignificant, opens a prospect of the formulation of the question about the moral choice associated with the question of the form of the question: whether it presupposes ressentiment or not. One of the Nietzsche's most important themes is the ground of the highest moral requirements, receiving bizarre forms of fine or terrifying aphorisms. "Unhappy do I call all those who have only one choice: either to become evil beasts, or evil beast-tamers. Amongst such would I not build my tabernacle"[12], says Zarathustra in one of his speeches. The choice between the two forms of "ferocity" is not a choice. One can only understand it in formulating such aphorisms that form images in which the old truth about choosing the lesser of two evils takes on a new meaning of searching of many possible perspectives.

\section{REFERENCES}

[1] Jaspers K. Nietzsche and Christianity. Chicago: Henry Regnery Company, 1967.

[2] Heidegger M. Nietzsche. Vol. 1. HarperOne, NY, 1991.

[3] Bazargani D.T., Larsari V.N. "Postmodernism": Is the Contemporary State of Affairs Correctly Described as 'Postmodern'? // Journal of Social Issues \& Humanities. January 2015. Vol. 3. Iss. 1. P. 89-96.

[4] Markov B.V. Heidegger and Nietzsche // Internet-project «Filosofskaya antropologiya». URL: http://anthropology.rchgi.spb.ru/nicshe/nitshe_i3.htm.

[5] Nietzsche F. On The Genealogy of Morality. Tr. by C. Diethe. Cambridge, Cambridge University Press 2006.

[6] Kosorukova AA., Lapshin IE., Mukhametzhanova VS. Aesthetic Moralism as a Form of Overcoming Nihilism: Ethical-Pedagogical Ideas of F. Nietzsche. In: Proceedings of the International Conference On Arts, Design And Contemporary Education 2016; 2016 May $23-$ 24; Moscow, Russia. Netherlands: Atlantis press; 2016. p. 1308-1311.

[7] Mamardashvili M.K. Classical and non-classical ideals of rationality. Moscow, 1994

[8] Aylesworth, Gary, "Postmodernism", The Stanford Encyclopedia of Philosophy (Spring 2015 Edition), Edward N. Zalta (ed.), URL = <https://plato.stanford.edu/archives/spr2015/entries/postmodernism/>. 
[9] Deleuze, Gilles. Nietzsche and Philosophy, Hugh Tomlinson (trans.), New York: Columbia University Press, 1983.

[10] Derrida, Jacques. Of Grammatology, Gayatri Chakravorty Spivak (trans.), Baltimore: Johns Hopkins University Press, 1974.

[11] Nietzsche F. Thus spoke Zarathustra. R.J. Hollingdale. UK, Penguin Classics, 2003.

[12] Nietzsche F. Thus spake Zarathustra. (Fiction, 1892, 386 pages) Thomas Common (translator). URL: http://www.literaturepage.com/read/thusspakezarathustra.html.

[13] Kosorukova A.A. Problema dobrodeteli v pozdnikh proizvedeniyakh F. Nitsshe // Vestnik Rossiiskogo universiteta druzhby narodov. Seriya «Filosofiya». - 2013. - №3. (Kosorukova AA. The problem of virtue in the later works of F. Nietzsche. Journal Vestnik Rossiiskogo universiteta druzhby narodov. Seriya «Filosofiya». Moscow 2013. №3.)

[14] Diethe, Carol. Historical Dictionary of Nietzscheanism. Lanham, The Scarecrow press, INC. 2014.

[15] Nietzsche F. On The Genealogy of Morals. III, 24. UK, Penguin Classics, 2013. 